\title{
Viscum album citotoxicity in Caco-2 cells (in vitro) analyzed by Dispersive Raman Spectroscopy
}

\author{
Daniela Franco Lopes (MD Vet MSc) \\ Advisor: Landulfo Silveira Junior (PhD) \\ Universidade do Vale do Paraíba, SP, Brazil
}

In the last decades, it has been observed a gradual increase in the diagnosis of neoplasm in both human beings and animals. This can be attributed to the advances in research and technology, which facilitated detection, promoting, thus, survival. On the other hand, the current incidence of cancer may also be attributed to an excess of chemicals in food products, radiation arising from antennae, environmental pollutants, indiscriminate use of hormone therapies, besides genetic alterations. Conventional oncologic treatments traditionally employ chemotherapic drugs. Later on, vegetal immunomodulators were also introduced, such as Viscum album. In the present study, the effectiveness of injectable extract Viscum album was tested in vitro in Caco-2 cells, in dilutions D3

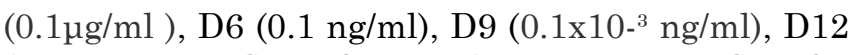
$\left(0.1 \times 10^{-6} \mathrm{ng} / \mathrm{ml}\right)$ and D30 $\left(0.1 \times 10^{-6} \mathrm{ng} / \mathrm{ml}\right)$. The optical method used was the Dispersive Raman Spectroscopy at $830 \mathrm{~nm}$ by comparison to MTT Assay. The results showed that Viscum album has an action on mitochondrial activity, reducing cellular viability in Caco-2 cells in dilutions D3, D6 and D9. Correlation of Raman spectrum to the values obtained in the MTT test was statistically analyzed by PLS, revealing a sensitive tool for the detection of changes in the mitochondrial activity of Caco-2 cells. Raman spectroscopy is a non invasive diagnostic procedure, allowing for real-time diagnosis and reduction of costs, besides indicating the best therapy for each type of tumor as well as modifications in the therapeutic strategy.

Keywords: Injectable homeopathy; Neoplasm; Colon; Cell cuture; MTT Assay; Dispersive Raman Spectroscopy.

\section{Results}

Figure 1. Raman spectra of five samples of Caco-2 cells with the following dilutions of Viscum album (from top to bottom): D3 (0.1 $\square \mathrm{g} / \mathrm{ml})$, D6 $(0.1 \mathrm{ng} / \mathrm{ml})$, D9 $\left(0.1 \times 10^{-3} \mathrm{ng} / \mathrm{ml}\right)$, D12 $\left(0.1 \times 10^{-6}\right.$ $\mathrm{ng} / \mathrm{ml})$, D30 (0.1×10-24 $\mathrm{ng} / \mathrm{ml})$.

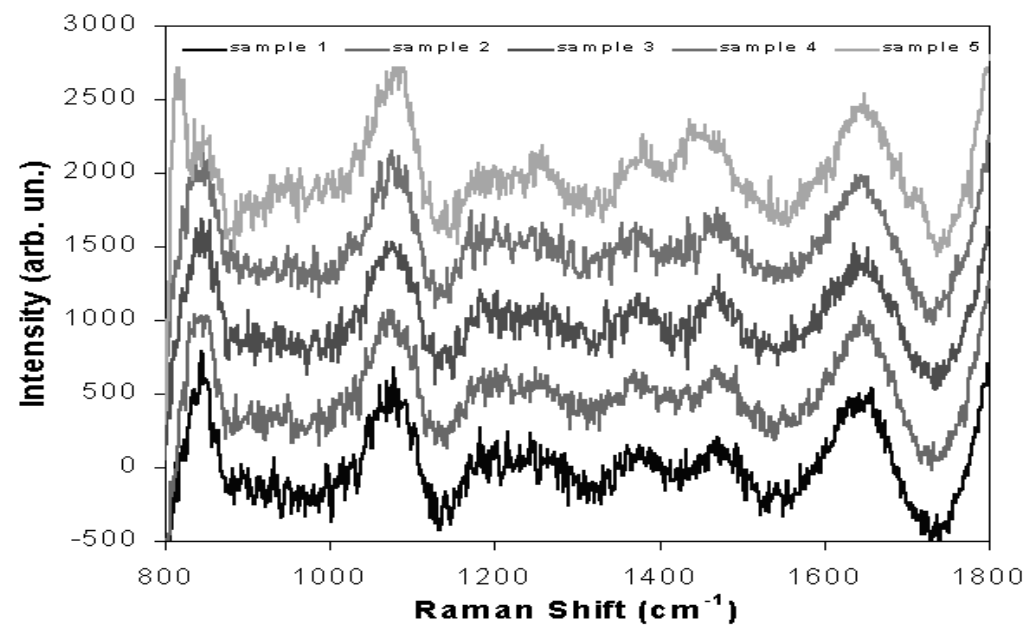


Figure 2. Plot of the first two latent variable spectra of the PLS model, showing main spectral characteristics that appear in the Raman data.

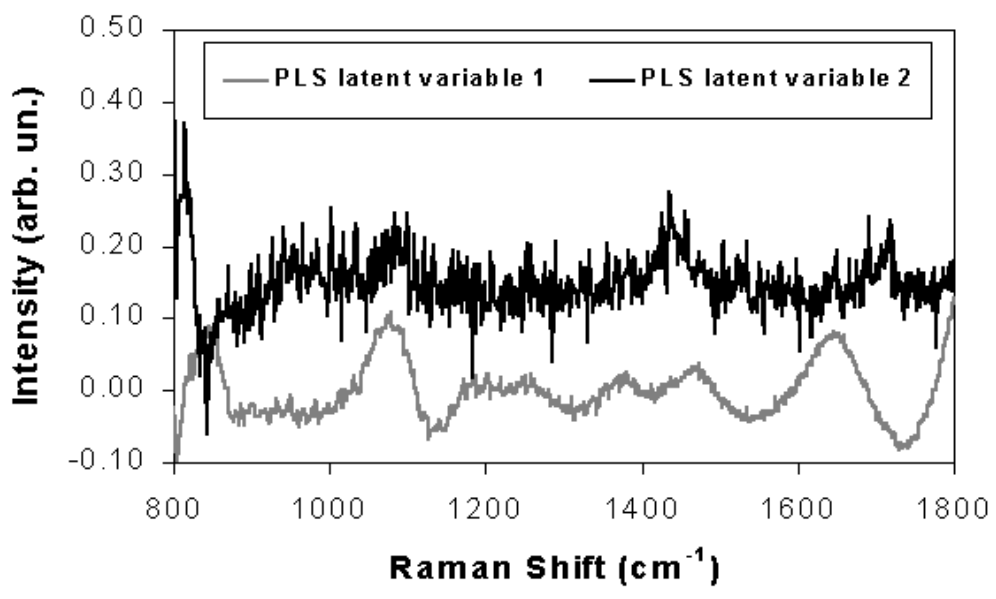

Figure 3. Plot of the MTT assay versus the PLS assay calculated from the Raman spectra using the second latent variable.

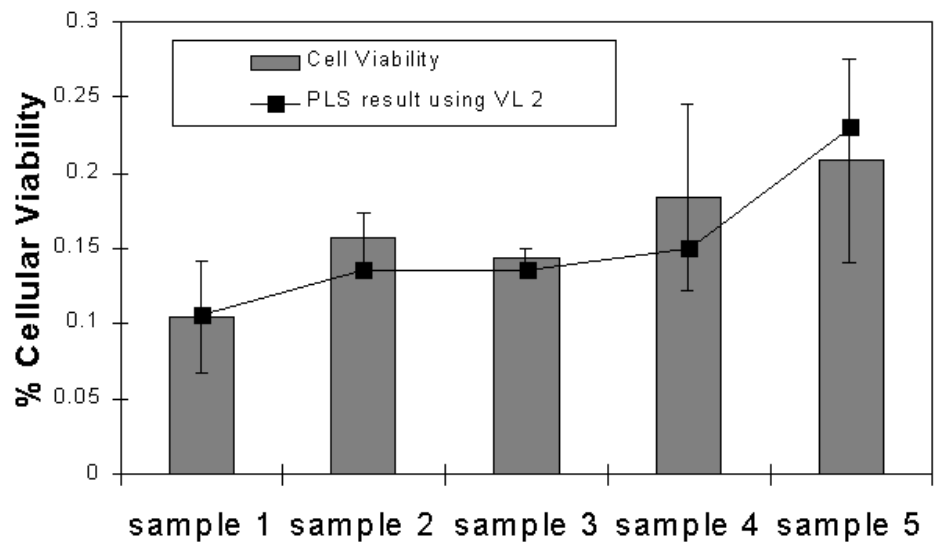

\section{(cc) EY-NC-ND Licensed to GIRI}

Support: InjectCenter/Homeocenter

Conflict of interest: author declares there is no conflict of interest

Received: 24 May 2008; Revised 11 June 2008; Published: 30 June 2008

Erratum: 30 Dec 2008. (http://www.feg.unesp.br/ ojs/zacha_ijhdr/erratum/?v=7\&i=23\&pi=118)

Correspondence author: Daniela Franco Lopes, UNIVAP, danielavethomeopata@yahoo.com.br

How to cite this article: Lopes DF. Viscum album citotoxicity in Caco-2 cells (in vitro) analyzed by Dispersive Raman Spectroscopy [thesis]. Int J High Dilution Res [online]. 2008 [cited YYYY Mmm DD]; 7(23): 118-119. Available from: http://www.feg.unesp.br/ ojs/index.php/ijhdr/article/view/272/347. 